\title{
Abrogation of the Therapeutic Model in Prison Health Care and the Implications for Public Safety Susan Nagelsen and Charles Huckelbury
}

T

he United States, long acknowledged as the principal advocate of incarceration as a means of social control, continues to lead the world in imprisoning its citizens, even in the face of declining crime rates and economic crisis. Many state governments also continue to defy the industrialized world's call for an end to capital punishment. According to the Pew Center's Public Safety Performance Project, at the beginning of 2008, the country's prisons and jails housed 2,319,258 men and women. The per capita figure of 750 prisoners per 100,000 adults ranks ahead of Russia's 628 per 100,000 and the raw numbers exceed China's secondplace finish of 1.5 million adults (Crary, 2008, A2). The burden such a policy imposes on the economy is onerous: $\$ 60$ billion spent in $2007^{1}$ versus $\$ 11$ billion spent in 1987 , an increase six times greater than the increase in funding for higher education, a counterproductive approach that underwrites "soaring costs that [states] can ill afford and [that] fail to have a clear impact on either recidivism or overall crime" (ibid).

President George W. Bush tacitly promotes such a feckless approach by alternately cajoling and threatening Congress to pass more intrusive legislation that would continue the government's practice of spying on anyone it chooses without judicial oversight. ${ }^{2}$ Such a tactic promotes a climate of fear and obviates existing legal safeguards. He has nevertheless been successful in persuading the electorate to support an uncompromising approach to criminal justice issues, resulting in public approval for rendition, secret prisons, indefinite incarceration and even torture, in spite of the fact that when polled, 87 percent of Americans prefer a rehabilitative model rather than punishment for incarcerated Americans. ${ }^{3}$ Although this is not an environment in which abolitionist proponents would normally be sanguine, possibilities for progress do exist.

\section{The Perceptual Fallacy}

The United States continues to imprison people at a rate unequalled by any society at any other time in recorded history and yet most people have no contact with the criminal justice system, getting their news and forming their opinions in the insulated environment of their living rooms. This creates a perceived disconnect between their lives and those of the men and women sentenced to prison. They therefore arrive at the conclusion 
that prisoners more or less get what they deserve for committing their crimes and if they suffer a little physical pain or deprivation in the process that does not keep many people awake nights. One of us (Nagelsen) brought this information to students and asked what they thought about the United States having 2.3 million men and women behind bars. One student responded, "I think the cops are doing a good job".

Robert Johnson, in his book Hard Time: understanding and reforming the prison $(2002$, p. 21) puts this attitude in a historical context of society's predilection for isolating "dangerous" people: "[T] he notion of confinement... would derive from reactions to recurring experiences in nature, particularly those that posed threats to the survival of the species. The original threat...was probably contagious disease". Prior to the identification of pathogens and disease vectors, banishment continued until the illness had run its course or the patient died. Thus, expulsion from the community was a natural way to "prevent [infection] of the healthy" (ibid).

Given the primitive state of medical knowledge and the prevalence of superstition, it is not surprising that disease has historically assumed a mystical guise, one that implied the moral imperfection of the suffering individual, much as the Old Testament prophets ${ }^{4}$ castigated specific elements of the community for their apostasy or pointed a finger at Jerusalem's destruction and the Babylonian exile as evidence that they got what they deserved. As Johnson (2002, p. 21) puts it, "[c]onfinement would punish the infected people for their impurity in a way that [was] poignantly symbolic". The segment of the community who remained healthy would thus see no connection between their own "purity" and the contamination of those it ostracized, caring little about their welfare. The theme Foucault explores in his book Discipline and Punish: The Birth of the Prison (1977), of course, offers a similar description of the link between disease and confinement when he speaks of prison as evocative of the leper colony, where those confined are cut off from all contact with those left behind.

Contemporary attitudes have remained consistent with the historical models elucidated by Johnson (2002) and Foucault (1997), as disease remains a common metaphor when discussing men and women cast out from society to serve their prison sentences. Moreover, their treatment while they are imprisoned mirrors the same response that characterized preliterate societies: onset of disease or chronic disorders arouses neither sympathy nor empathy among those charged with their care. Explanations for such an insensitive reaction usually include a nexus of the substandard qualifications of the health-care providers and the 
public's attitude toward those it imprisons - each inextricably wedded to the other.

\section{Compromised Credentials}

Imagine employment representatives coming onto a college campus and recruiting from the bottom quartile of the graduating class. Further, imagine a professional firm hiring applicants with histories of misfeasance, malfeasance and even criminal misconduct, including having their pertinent licenses either revoked or suspended in other locations. Now consider the potential results of placing those same cohorts in decisionmaking positions that will ultimately affect the health and welfare of hundreds of thousands of men, women and children. It would be the equivalent to appointing a disbarred personal-injury lawyer with limited legal experience Attorney General or Lord Chancellor.

This simple thought experiment should produce alarms across the political spectrum and in every social stratum. And yet, Western societies continue to accept and even encourage the practice without question, or, if questions arise, justify the pattern in financial terms. The very real potential for facilitating the spread of diseases like HIV/AIDS, drug-resistant tuberculosis and hepatitis $\mathrm{C}$ into the community, however, hardly validates the putative economic benefits.

Substandard medical care inside prisons is incarceration's worst kept secret. Although industry publications avoid them, legal journals are replete with synopses of legal settlements against prisons and jails responsible for injuring or killing prisoners. The causes run the gamut of medical malpractice, from withholding medication to misdiagnosis to collusion in concealing physical abuse. Prison Legal News, for example, recently described a diabetic federal prisoner who was given insufficient doses of insulin. After suffering a blackout, the prisoner complained and was sent to segregation instead of the hospital. Because the prison was run by a private contractor, those responsible for denying his medication were not liable under federal law (Prison Legal News, 2008, p. 16).

In Delaware, for example, the state Department of Corrections hired a private contractor to provide health care to prisoners. ${ }^{5}$ A United States Department of Justice report found that the contractor was not interested in attracting and retaining "individuals that would be qualified to fill vacant positions". Efforts to reduce costs included assigning licensed practical nurses (LPNs) to positions normally held by registered nurses, such as screening new arrivals for communicable diseases, including tuberculosis. The DOJ report, however, stated that "LPNs typically do not have appropriate education and training to perform exploration of medical 
symptoms" (Reutter, 2008, p. 25). The obvious conclusion is that if the health care providers in the Delaware DOC did not care enough to provide adequate screening for incoming prisoners, treatment would have been equally indifferent, resulting in contagious individuals being released into the community.

Notwithstanding well-known legal precedents in the United States, ${ }^{6}$ prison medical personnel in a disturbing number of institutions, both public and private, continue to inflict pain and suffering on a regular basis, irrespective of the dangers such practices pose to an unwitting public. Even terminally ill patients are not immune from such treatment.

Yvette Louisell is a life-term prisoner at the Women's Correctional Institution in Mitchellville, Iowa. Louisell, incarcerated as juvenile for a homicide twenty years ago, described an incident where she and a group of friends assisted a dying prisoner to the prison's infirmary for treatment because she could not keep anything down and was having difficulty standing. The nurse on duty told the women that she had already informed the patient that she was dying and that there was nothing she could do for her. She then ordered the women, including the dying woman, to return to their cells (Nagelsen, 2008).

The question of how this practice became accepted and even proliferated is one the public needs to ask, and the search for answers should begin with an examination of the credentials and professional records of the health care providers.

\section{Economic Determinants}

As the cost of higher education in the United States continues to climb, graduate degrees become progressively more difficult to afford for many qualified students. Even graduates with baccalaureate degrees enter the work force deeply in debt. The George Washington University, for example, recently increased undergraduate tuition and costs to over $\$ 50,000$ a year. ${ }^{7}$ These costs make state jobs and benefits even more attractive. When times are tough and the prospect of unemployment is looming, life as a prison guard becomes very attractive because it is one of the highest paid unskilled labour jobs in America.

Operating under legislative budgetary constraints, prisons cannot compete for these men and women who find far more lucrative careers in private practice, resulting in a concentration of providers with mediocre academic records, inferior training and disciplinary histories that automatically close the doors to traditional opportunities in the private sector. Prison then becomes, to paraphrase Samuel Johnson, the last refuge of the marginally qualified. 
The situation is aggravated in an era of fiscal austerity, when prisons often find themselves faced with mandatory cuts in funding, which usually begin with programs that then radiate outward to include such necessities as food and health care. Most prisons, for example, have now instituted some sort of co-payment procedure, whereby prisoners assume partial financial responsibility for going to sick call. These fees are often beyond the prisoners' means and as a result they choose to forego treatment. ${ }^{8}$ It is not rare to encounter cases where treatment was denied because the patient was nearing his parole date, the prison preferring to avoid incurring an expense that could be absorbed by the community instead. ${ }^{9}$

This pattern is inverted, however, in the case of geriatric prisoners, one of the most rapidly growing segments of the prison population at the rate of 10 percent per year (Nagelsen and Huckelbury, 2006). The Centers for Disease Control in Atlanta, Georgia, estimates an annual cost of $\$ 70,000$, or nearly triple that for younger men and women, to treat a geriatric prisoner for the diseases and conditions that are an expected part of the aging process, especially when "[m]ost prisons have neither the infrastructure nor the philosophical inclination to deal with geriatric conditions" (Nagelsen and Huckelbury, 2006, p. v). Rebecca Craig, the former president of the American Correctional Health Services Association confirms the pattern: "entire prisons [will be] licensed as acute care settings" (p. v).

And yet, instead of releasing infirm men and women, many of whom are not ambulatory, or diverting them to community-based programs where they could be controlled and monitored just as easily, they remain in an environment that should be the last option reserved for the most dangerous prisoners. This bizarre practice of releasing prisoners who pose a health threat to the public while keeping those who do not siphons off limited resources that could and should be applied to critical care needs, increasing the risk of local or even national epidemics in the process.

Aggravating an already dangerous situation are prison administrations that tend to subordinate all operational programs and services to security needs. Read the mission statement of any prison and the first sentence will articulate the duty of protecting the public, which naturally means elevating the security and operation of the physical plant to priority status. This philosophy results in a zero-sum solution to every funding crisis. Given the choice between hiring two more correctional officers or one more registered nurse, salaries will be diverted to security first.

Such stark choices, however, fall into the category of the either-or logical fallacy, as if no other options existed, which is clearly not the 
case. Laos Schumann is serving a twenty-five to life sentence at The Men's Colony in California. He has devoted his time in prison to helping those prisoners who suffer from HIV/AIDS. While he was imprisoned at Vacaville, he and other prisoners began a program that was eventually funded by the state to start a hospice program for dying prisoners. It was the first of its kind in the state and he has done the same at The Men's Colony where he is now housed (Nagelsen, 2008).

The lack of qualifications of some prison medical personnel, coupled with a gross indifference to the suffering of their patients, is not, however, universal. Unfortunately, the men and women who possess the fundamental education, training and empathy necessary to discharge their obligations professionally are often compelled to work with - and at times for - others who share neither their qualifications nor philosophy. It is the latter group who is responsible for the vilification of the entire staffs' reputations, and putting their patients and the public at risk for communicable diseases.

\section{Public Collusion}

Restricting health services to prisoners is myopic in the extreme. Although the immediate result is a deterioration in the prisoner's overall physical well-being, the repercussions do not stop there as the potential for contracting a communicable disease devolves to the communities to which over 90 percent of prisoners will return. The danger is especially acute if the prisoner is unaware that he or she is infected.

Even if all infected prisoners had life sentences, they would still pose a threat to prison staff who could then transmit the diseases to their families and others with whom they came in contact. Given the incidence of HIV/AIDS and hepatitis $\mathrm{C}$ in American prisons, ${ }^{10}$ delaying or refusing treatment - or in many cases, refusing routine testing to detect the disease - verges on the suicidal. ${ }^{11}$

That dire potential for mass infection appears to have eluded the public consciousness and is perhaps the underlying cause of inferior health care in prisons, tolerating and at times encouraging unnecessary suffering. This tendency of the public to support a punitive model of incarceration, one that limits programs and services to a bare minimum, while enforcing strict discipline and austerity, reflects attitudes based largely on misconceptions fuelled by media reports or entertainment versions of prisons and prisoners.

Elected officials are often complicit in this disinformation campaign, constantly urging citizens to accept more restrictions on their freedom and 
implying that those under arrest or serving prison sentences are benighted members of a subspecies, and therefore less deserving of the consideration extended to the untainted population. This government-inspired terror unfortunately gains credence from real-life tragedies, like those recently played out on the campuses of Northern Illinois University and Virginia Tech, where students and faculty were killed by gunmen who subsequently committed suicide. ${ }^{12}$

Threat inflation is, of course, hardly a novel political tool. In a recent essay, "The Greatest Threat to Us All", in the New York Review, Joseph Cirincione (2008, p. 19) observed, "[t] he manipulation of fear to promote programs that Americans would otherwise not support is different from honest disagreement over the scale of the threats". Indeed it is, as recent history confirms. Recall the hyperbole by government officials who orchestrated a campaign that convinced a supermajority of the American public that torture, secret prisons and indefinite imprisonment without trial or representation, even when applied to American citizens, was necessary to protect the "homeland". How easy, then, to point to men and women who have actually committed illegal acts to justify their mistreatment on that basis, with the assumption that nothing done to them will reverberate in the community from which they came.

\section{The Opposition}

Changing the public's attitudes will not, however, be easy. Jeff Neal, a spokesman for Rhode Island's governor, Don Carcieri, puts the conflict in perspective: "If we don't find a way to better manage the population at the state prison, we will be forced - to spend money to expand the state's prison system - money we don't have" (Henry, 2008, A2). Although many states are now facing the same woes, all frame the argument in terms of a management problem, not a philosophical epiphany.

Individuals and groups with long-term interests in maintaining the status quo are more forthright, if perhaps overwrought. Lynn Heaton, a police officer in Providence, Rhode Island invokes the shibboleth of public security to forestall any change in policy: "You're talking about victim [and] community safety. You can't balance the budget on the backs of victims of crime" (Henry, 2008, A2). Jerry Dryer, the Chief of Police in Fresno, California, echoes Heaton's alarm, maintaining that moving from a carceral model to a rehabilitative one "will ultimately jeopardize safety in communities". Finally, Terrence Jungel, the executive director of the Michigan Sheriffs' Association asserts that "Economics cannot be the engine that drives the train of public safety" (Henry, 2008, A2). 


\section{A ShIP ON The Horizon}

These two examples are instructive both for their methods and their successes in reversing what had been hard-wired public opinions. Incremental change must therefore be the key to reducing and eventually eliminating prisons as well. Even in the United States one can find reason for optimism. Congress recently approved, for example, amendments to the United States Criminal Code to eliminate the disparity in penalties between possession of crack and powdered cocaine, which will conceivably result in the release of thousands of current prisoners. ${ }^{13}$ Until that change, possession of one ounce of crack carried the same penalty as possession of ten times that amount of powdered cocaine.

The law had racial overtones as well, because most crack convictions were of minority defendants. ${ }^{14}$ Even so, previous efforts to correct this fundamental injustice got nowhere in the face of vigorous opposition and public outcry. This time, however, the modifications met with only token resistance, proving that consistent effort and measured change are the most viable methods to effect a social transformation.

Efforts to halt the carceral juggernaut are also making inroads at the state level. Susan Urahn, managing director of the Pew Centre's Public Safety Performance Project, says, "We're seeing more and more states being creative" in order to relieve the financial strain. Even law-and-order bastions like Texas and Kansas are "making greater use of community supervision for low-risk offenders" (Crary, 2008, A2).

Eight states are now considering transferring qualified prisoners to rehabilitation programs at an estimated savings of $\$ 450$ million in California and Kentucky alone, acknowledging that "treatment, which is cheaper than prison" is the trend to follow. Such programs, contrary to the ominous warnings of opponents, exclude violent offenders and those guilty of committing sexual offences (Henry, 2008, A2). As David Muhlhausen of the conservative Heritage Foundation admits, the reasoning transcends a strictly fiscal analysis: "We need to be smarter. We're probably incarcerating people who don't need to be" (Crary, 2008, A2).

\section{A Modest Proposal}

The number of men and women in prison in the United States is morally unjustifiable and economically unsustainable. As Senator Bernie Sanders (I-VT) puts it, "[t]hese sad facts reflect a very distorted set of national priorities" (Crary, 2008, A2). His observation is especially relevant when considering that over 53 percent ${ }^{15}$ of the men and women in the federal 
system were convicted for non-violent possession or use of drugs, many of whom are infected with HIV/AIDS or Hepatitis C. Transferring these men and women, as well as geriatric patients, into community-supervised, out-patient treatment programs to take advantage of existing staff and resources already in place (Medicaid, Medicare) would accomplish two things: 1) emptying prison cells; and 2) freeing money that could then be used to attract more competent personnel inside the remaining facilities.

Barbara Sampson, chair of the Michigan Parole Board, recognizes that if the goal is to equip prisoners who will re-enter society with the tools necessary to succeed, the deracinating process that inheres inside contemporary prison compromises that objective: "Getting that prisoner back to the community so that he can stay connected to his family, getting him back into the work force ... that's a positive thing" (Henry, 2008, A2). Evidence that supports this self-evident observation abounds.

Since 1952, the St. Anthony Foundation has operated a 315-acre organic dairy farm outside Santa Rosa, California. During a six-month program, addicts attend counselling and daily recovery classes with the physical labour the farm requires. The convergence of introspection and meaningful work, according to John Glionna (2008, A2), promotes a healing that "comes from being a part of something bigger than yourself, from putting the needs of others first".

The proposal is perhaps an ambitious beginning, considering the size of the prison population involved. Prison officials, however, can easily identify those low-risk men and women who would be most expected to benefit from such a shift in treatment and housing. A small transfer from a minimum-security facility would therefore be a logical place to launch such a strategy, keeping in mind that the program must quickly demonstrate its efficacy in terms of treating diseases, preventing their spread and reducing antisocial behaviour, ${ }^{16}$ all of which the community will support, especially if accompanied by a substantial savings by shrinking a monolithic system with a reputation for being grossly cost ineffective.

Strictly economic arguments for abolition will not, however, carry the day. Each prisoner in the United States costs the taxpayers an average of $\$ 23,876$ per year (Crary, 2008, A2) and Americans have repeatedly demonstrated their willingness to pay that price, often compromising their children's education in the process. Neither will a moral argument win the battle, because most Americans and most citizens of Western societies continue to express a faith in a version of St. Anselm's ontological argument that prisons must exist simply because we can conceive of them as the greatest good. Only by establishing a bridge between prisoners and the community will abolition become a reality. The first step along 
that difficult road must be recognizing the literal threat current health care policies pose to the public, while also moving selected prisoners out of their cells and into community-based facilities where they will be adequately treated.

Prior to the Civil War, abolitionists knew they were engaged in a struggle that had no immediate conclusion. After the war and ratification of the 13th and 15th Amendments, the civil rights movement fought pitched battles against a philosophically entrenched opposition that denied the fundamental humanity of African Americans and adopted lynching as the primary tool of oppression. And yet those warriors never surrendered their dream, as Martin Luther King, Jr. so eloquently described. The result was a series of relatively small events that eventually culminated in Barack Obama becoming the nation's first black President.

Just as their slavery abolitionist predecessors refused to countenance defeat, prison abolitionists must also look to modest victories that will lead to a major shift in public sentiment, and not be discouraged by the hostility and determination of those dedicated to maintaining the morally bankrupt and financially insupportable prison industry. We cannot give up hope - there are too many lives at stake.

\section{ENDNOTES}

1 Katzbenbach (2006) "Confronting Confinement: A Report of the Commission on Safety and Abuse in Prison", p. 13. See www.prison.commission.org.

2 FISA. ACLU. See www.aclu.org/safefreee/spying/fisa.html.

3 Katzbenbach (2006) "Confronting Confinement A Report of the Commission on Safety and Abuse in Prison", p. 14. See www.prisoncommission.org.

4 E.g., Jeremiah.

5 Correctional Medical Services (CMS).

6 See Estelle v. Gamble, a US Supreme Court case that specifically defines deliberate indifference to a patient's pain and suffering as a violation of the 8th Amendment to the Constitution prohibiting "cruel and unusual punishments". See www.law. cornell.edu/supct/html/historics/USSC_CR_0429_0097_ZS.html.

7 The George Washington University. See colonialcentral.gwu.edu/.

8 In a study conducted by the Centers for Disease Control and Prevention to evaluate the cause of outbreaks of methicillin-resistant Staphylococcus aureus (MRSA) in correctional facilities in Georgia, California, and Texas between 2001 and 2003, copayments were singled out as a significant contributor to the spread of these serious and aggressive skin infections because they discouraged prisoners from seeking care (CDC, 2003).

9 Many prisoners are routinely asked how much longer they have to serve before treatment or therapy proceeds. 
10 According to "Confronting Confinement", in 1996 there were between 98,000 and 145,000 prisoners released with HIV, along with 39,000 with AIDS. There were 1.3 million released with Hepatitis C, 566,000 with latent Tuberculosis and 12,000 with active TB. See www.prisoncommission.org.

11 The New Hampshire State Prison in Concord, for example, recently discontinued annual physical examinations, including the standard test for tuberculosis. This includes prisoners assigned to food service.

12 During the early morning hours of April 16, a gunman went on a rampage on the Virginia Tech campus. By the time he was done, more than 30 students and faculty members were dead. See http://www.cnn.com/SPECIALS/2007/virginiatech. shootings/. At Northern Illinois University on Feb 15, 2008, a 27-year-old gunman opened fire in a lecture hall Thursday, killing five people and wounding 15 before taking his own life. See www.npr.org/templates/story.php?storyID=19082.

13 Lewis (2007) "Sentencing Panel Changes Crack Recommendation" - May 15. See www.npr.org/templates/story/story.php?storyId=10192763.

14 (2001) Race, The War on Drugs and the United States Criminal Justice System Drug Policy Alliance - August. See http://www.drugpolicy.org.

15 The Department of Justice reported that by September 30, 2006, 53 percent of federal prisoners were drug offenders. In 2000, 56 percent were drug offenders in federal prisons. See www.drugwarfacts.org/prisdrug.htm.

16 We recommend intense program participation, including one-on-one therapy, as part of the treatment plan and employment counselling to eliminate the need for illicit activity to support one's addiction.

\section{REFERENCES}

Cirincione, Joseph (2008) “The Greatest Threat to Us All”, New York Review of Books: pp. 18-21 - March 6.

Centers for Disease Control (CDC) (2003) "Methicillin-Resistant Staphylococcus aureus Infections in Correctional Facilities - Georgia, California, and Texas, 20012003", CDC Weekly - October 17, retrieved from http://www.cdc.gov/mmwr/ preview/mmwrhtml/mm5241a4.htm

Crary, David (2008) "Study: More than 1 in every 100 Americans in jail", Concord (NH) Monitor: A2 - February 29.

Foucault, Michel (1977) Discipline and Punish: The Birth of the Prison, New York: Pantheon.

Glionna, John M. (2008) "Rural Rehab", Concord (NH) Monitor: A2 - April 4.

Henry, Ray (2008) "States ponder releasing inmates to save money", Concord (NH) Monitor: A2 - April 4.

Johnson, Robert (2002) Hard Time: understanding and reforming the prison, Belmont, CA: Wadsworth.

Katzbenbach, Nicholas (2006) "Confronting Confinement A Report of the Commission on Safety and Abuse in Prison", last retrieved in May 2006 from www. prisoncommission.org. 
Lewis, Libby (2007) “Sentencing Panel Changes Crack Recommendation", last retrieved in June 2007 from www.npr.org/templates/story/story.php?storyId=10192763.

Nagelsen, Susan (ed.) (2008) Exiled Voices, Portals of Discovery, Henniker (NH): New England College Press.

Nagelsen, Susan and Charles Huckelbury (2006) "Introduction", Journal of Prisoners on Prisons, 14(2): v-x.

Prison Legal News (2008) “Bivens Action Inapplicable to Private Prison Employees", pp. 16-17 - January.

Reutter, David M. (2008) "Independent Monitor Issues First Report on Delaware Health Care”, Prison Legal News, pp. 24-25 - February.

\begin{abstract}
About the Authors
Susan Nagelsen is Director of the Writing Program at New England College in Henniker, New Hampshire, where she has taught for twentyfour years. She is an essayist and a fiction writer as well as the author of two writing manuals. She teaches first-year courses as well as advanced essay writing courses such as the art of the essay and content based writing. She also teaches in the Criminal Justice program where her course focuses on teaching students about prison from the point of view of prisoners. Her most recent published fiction can be found in the fall 2005 edition of the Henniker Review, Tacenda, Bleakhouse Review and in the Journal of Prisoners on Prison Volume 14(2), an issue addressing aging in prison. She is a frequent contributor to the $J P P$ and is currently Associate Editor. She is the editor of an anthology of work by incarcerated writers entitled Exiled Voices, Portals of Discovery (2008) New England College Press. The book features 13 incarcerated writers with an introduction to each written by Nagelsen and is being used as a textbook in courses focusing on criminal justice issues.
\end{abstract}

Charles Huckelbury was sentenced to life imprisonment (thirty-five year minimum) at the age of twenty-seven and has spent the last twenty-eight years in prison. Awarded second place in Prison Life's fiction contest in 1995, he won the PEN first prize for fiction in 2001. A regular contributor to the JPP since 1997, Charles joined the Editorial Board in 2001 and is now an Associate Editor. He was one of four featured writers in Shawn Thompson's Letters From Prison (2001). His new book of poetry, Tales From the Purple Penguin (2008) has received rave reviews from students and academics. 